International Review of Research in Open and Distributed Learning Volume 20, Number 2

April - 2019

\title{
Master's Students' Perceptions and Expectations of Good Tutors and Advisors in Distance Education
}

Mehmet Kara ${ }^{1}$ and Gulfidan Can ${ }^{2}$

${ }^{1}$ Amasya University, ${ }^{2}$ Middle East Technical University

\begin{abstract}
The purpose of this study was to explore non-thesis Master's students' perceptions and expectations of good tutors and advisors in distance education programmes. It also examined whether these perceptions and expectations are related to student characteristics including age, gender, university, programme, semester, and previous online learning experience. The current study was conducted within the framework of Transactional Distance Theory. Using a mixed methods approach, a questionnaire was administered to 143 students in four programmes in two universities in Turkey and interviews were conducted with 11 of these students. Results showed that good tutors and advisors in distance education provide a stimulating studentcentred learning environment, have a caring and individualised interaction and communication with students, and have subject expertise and basic technology skills. The results of this study will improve distance education tutors and advisors' practices in supporting graduate students' education and research.
\end{abstract}

Keywords: tutor, advisor, distance education, graduate students' perceptions, graduate students' expectations 


\section{Introduction}

Distance Education (DE) can be defined as "teaching and planned learning in which teaching normally occurs in a different place from learning, requiring communication through technologies as well as special institutional organization" (Moore \& Kearsley, 2011, p. 2). In 2014, while enrolments for regular Higher Education programmes declined in the U.S., DE enrolments increased, including graduate programmes (Allen, Seaman, Poulin, \& Straut, 2016). Similarly in Turkey, the number of universities offering DE programmes and the number of DE students are continually increasing (Higher Education Council [HEC], 2016). For graduate students, common reasons for increased enrolment in DE may include fulfilling a desire for lifelong learning, global and equitable access of courses, need for promotion, and flexibility of learning considering the restrictions of adult life (Wisker, 2012). However, graduate student attrition rates are also high, especially in DE (Stoessel, Ihme, Barbarino, Fisseler, \& Stürmer, 2015). Due to this increasing number of student enrolments, DE requires further attention to ensure the success of its programmes, student learning, and retention.

Within the context of this study, DE tutors and advisors differ only in terms of their responsibilities. While both are usually full-time faculty, in Turkey, a tutors' main responsibilities include designing and delivering courses, while an advisors' main responsibility is to supervise student research projects. Therefore, curriculum may require tutors to assume the role of advisors. Moreover, advisors are not only expected to support graduate students with learning and research, but also with their socialisation and enculturation to the discipline (Gardner \& Mendoza, 2010). These different roles may affect the type of competencies they need to develop to provide improved support to graduate students (Bawane \& Spector, 2009).

The literature documents that tutor-related issues are one of the most important success factors for DE programmes (Soong, Chan, Chua, \& Loh, 2001) and that graduate students perceive tutors as their main academic support (Cain, Marrara, Pitre, \& Armour, 2007). Within the theory of Transactional Distance, Moore (1993) suggested that the success of DE programmes relies on the tutor's role in adjusting dialogue and course structure based on student needs. However, students' conceptions of a good DE tutor might differ from the education providers (Abdulla, 2004; Dennen, Darabi, \& Smith, 2007). Therefore, improvements in DE programmes should be guided by learners as well as experts.

Students' expectations influence their course experience, and their attitude towards the experience influences the types of support they need (Howland \& Moore, 2002). For example, students with a more constructivist approach to learning expect to be independent learners, while other students may rely more on the experts' knowledge, validation, continuous feedback, and a well-structured course (Howland \& Moore, 2002). However, regardless of thelevel of self-regulation skills, students need tutorial support when applying new knowledge (Moore, 1989).

Aside from their level of education, student perceptions and expectations may also vary with other factors including age, gender, subject area (J elfs, Richardson, \& Price, 2009), level of experience in online courses (Huang, 2002), and context (Bawane \& Spector, 2009). Furthermore, the few international studies found to explore graduate students' opinions frequently used either quantitative (e.g., Young, 2016) or qualitative methods (e.g., Edwards, Perry, \& Janzen, 2011). Consequently, it is crucial to explore which tutor and advisor characteristics constitute a "good tutor" and a "good advisor" according to distance education 
graduate students in light of the aforementioned factors and through more comprehensive data collection methods. Therefore, this current study investigates non-thesis Master's students' perceptions and expectations of good tutors and advisors in DE programmes by considering students' general characteristics (age, gender, semester, previous online experience), and context (university, programme) through a mixedmethods research design.

\section{Relevant Research}

From a theoretical perspective, Transactional Distance (TD) is defined as "a psychological and communications space to be crossed, a space of potential misunderstanding between the inputs of instructor and those of the learner" (Moore, 1993, p. 22). TD theory explains the interplays of TD, course structure, dialogue, and student autonomy in distance education to reach learning outcomes. This theory suggests that a well-designed learning environment with ample opportunity for interaction and discussion may reduce the psychological and communicational distance students feel in DE. Giossos, Koutsouba, Lionarakis, and Skavantzos (2009) reconsidered TD theory and proposed that teacher actions are the inputs of the DE system producing TD as an outcome through the mechanisms of dialogue, structure, and autonomy. Similarly, several research studies revealed that teacher actions (e.g. Benson \& Samarawickrema, 2009; Huang, 2002; J oo, Andrés, \& Shearer, 2014; Lemak, Shin, Reed, \& Montgomery, 2005), course structure (Stein, Wanstreet, Calvin, Overtoom, \&Wheaton, 2005), and students' age (Huang, Chandra, DePaolo, \& Simmons, 2016) influence students' TD perceptions.

The main challenges of graduate DE students include engaging in the research culture of the university, dealing with isolation, self-regulating their learning, and effectively using online communication (Wisker, 2012). Wisker (2012) suggests that while working with students, DE supervisors should maintain a system of communication and support throughout the research process, prepare students for research, writing, and new forms of communication, and be sensitive to students' life and work demands. Supervisors should also provide constructive feedback, opportunities and online spaces and technologies for communication, and maintain dialogue toward successful and reciprocally satisfying research processes (Wisker, 2012). Although these suggestions are beneficial, few research studies reported the type of support students themselves expect from their tutors and advisors (e.g., Edwards et al., 2011; Holzweiss, J oyner, Fuller, Henderson, \&Young, 2014; Young, 2006).

Available studies about students' opinions reported a variety of qualities students expect from good tutors and advisors in graduate distance education. Results showed that students learned better when courses and assignments were relevant to real life; designed to improve their reflections, critical thinking, and problemsolving skills; and supported with a variety of tools including discussion forums, videos, videoconferencing, and online library research (Holzweiss et al., 2014). Students valued learning experiences that are challenging and meaningful (Edwards et al., 2011; Young, 2006).

Effective communication is a vital factor for the success of online programmes (Young, 2006). Students expect high connectivity with their tutors and advisors (Schroeder, Baker, Terras, Mahar, \& Chiasson, 2016), want to feel their tutor's presence online (Dennen et al., 2007), and expect timeliness in all 
communications (Cain et al., 2007). Therefore, availability for help was expected from tutors and advisors at predetermined times (Cain et al., 2007; Schroeder, 2012). Students had negative attitudes toward inadequate online discussion durations (Risner \& Kumar, 2016). While they expected advisors to promote peer interaction (Lessing \& Schulze, 2002), their need to communicate with tutors and advisors was higher than their desire to connect with other students (Schroeder et al., 2016).

Students expected their tutors to provide timely feedback, written feedback, constructive criticism, guidance for research especially for planning, scheduling, statistical analysis, reporting, interpretation, presentation of results, and literature searches (Cain et al., 2007; Dennen et al., 2007; Edwards et al., 2011; Holzweiss et al., 2014; Lessing \& Schulze, 2002; Young, 2006). They expected caring, guidance, and individualised advising (Schroeder, 2012). For students, effective tutors considered students' needs, motivated them for better performance, and respected them as valued individuals (Edwards et al., 2011; Holzweiss et al., 2014; Young, 2006).

Regarding assessment, students preferred to clearly know the tutors' expectations and preferred to see useful examples (Dennen et al., 2007; Howland and Moore, 2002; Young, 2006). Students had negative attitudes toward small assignments graded for quantity such as regular posting on discussion boards for points (Howland \& Moore, 2002).

The available studies rarely considered advisors' roles in students' projects or research. This might be because different countries and programmes have varying degree completion requirements. In Turkey, a project with research emphasis is required for non-thesis Master's degree completion. However, there is inadequate literature to guide the practice in Turkey. Furthermore, the available studies reported in this section used either quantitative or qualitative methods, whereas a more comprehensive understanding is needed. Therefore, this current study is conducted to investigate non-thesis Masters' students' perceptions of and expectations of good tutors and advisors in DE programmes, whilst also exploring variables that might relate to these perceptions and expectations, using a mixed methods research design to reach a comprehensive conclusion.

\section{Methodology}

The study's research questions follow:

1. What are the perceptions of students studying in non-thesis Master's programmes of good tutor characteristics in distance education?

2. Are there differences between these perceptions in terms of student age, gender, university, subject field, previous online learning experience, and the number of semesters spent in the programme?

3. What are students' expectations of good tutors and advisors in distance education? 
A mixed methods research design, specifically the concurrent triangulation strategy was employed (Creswell, 2007). First, a questionnaire was used to collect quantitative data, followed by interviews to collect qualitative data. Data were analysed separately, and their results compared and combined after completion of their individual analyses. Both data types have equal weight in this study.

\section{Participants and Data Collection}

The population of this study is students studying in non-thesis Master's DE programmes in Turkey. In 2015, of 47 public and private universities offering DE Master's programmes in Turkey (HEC, 2016), researchers had access to two public universities (U1 and U2) that were purposefully selected for their representativeness, based on their Learning Management Systems (LMSs). Their LMSs for DE represent the two most commonly used in these programmes in Turkey (Enocta and Moodle); representing 70\% of universities offering DE graduate programmes in Turkey for 2016. They both used Adobe Connect for online sessions. The distance education courses in both universities are conducted fully online except for students' final exams and the degree requirement of a research project. U1 had one programme and U2 had eight distance education programmes.

After the approval of the Human Research Ethics Committee in both universities, an online questionnaire was sent to all students in both universities. Their contact information was obtained from the Distance Education Research and Practice Centers (DERPC) which govern distance education programmes in Turkey. Due to limited response to the online questionnaire even with the reminders, the questionnaire was administered paper-based at the end of the semester when students came to campuses for final exams. In U1, all 75 students were given the questionnaire and 54 responded (response rate $72 \%$ ). In U2, due to administrative restrictions, 300 students in three programmes were given the questionnaire and 89 responded (response rate 29.7\%). Total number of participants was 143 and the total response rate was $38.1 \%$.

Based on the questionnaire results, respondents' ages ranged from 23 to 52 ( $M=32.10, \mathrm{SD}=5.91)$ with $22.4 \%$ $(\mathrm{n}=32)$ having had previous online learning experience. There were 99 female (69.2\%) and 44 male (30.8\%) students. Of the 143 participants, 37.8\% studied Classroom Teaching (CT) ( $n=54), 23.1 \%$ studied Health Institutions Management (HIM) ( $\mathrm{n}=33), 21.7 \%$ studied Nursing at Home $(\mathrm{NH})(\mathrm{n}=31)$, and $17.5 \%$ studied Educational Administration and Planning (EAP) $(n=25)$.

After the questionnaire's administration, semi-structured interviews were conducted with students who were working on their research projects. The students volunteered by writing their email address on the questionnaire. No students volunteered from U2. In U1, 11 students from the CT Programme volunteered out of 25 students, likely due to the rapport they had with the first author who worked in the programme as a content manager and support personnel. Seven male and four female students were interviewed. Their ages ranged from 24 to 31 ( $\mathrm{M}=27.27, \mathrm{SD}=2.33)$, and none had previous online learning experience. The interviews lasted an average of 20.54 minutes.

\section{Instruments}

The original questionnaire had five factors with a total of 33 five-point Likert-type items in the form of an agreement scale developed by J elfs, Richardson, and Price (2009) which was used to examine students' 
perceptions of a good tutor in DE, with the permission of the authors (e.g. item: "A good tutor helps students to adopt a critical approach"). These five factors were Critical Thinking (CT), Subject Expertise (SE), Pastoral Care (PC), Promoting Interaction (PI), and Vocational Guidance (VG). Several demographic items were added to the questionnaire in order to collect data about participants' age, gender, university, subject field, previous online learning experience, and the number of semesters spent in the programme. Since the language of instruction in U1 and U2 is Turkish, the questionnaire was translated into Turkish, and backto-back translated with confirmation from native speaker language instructors.

For each factor, Cronbach's Alpha Coefficients for internal consistency were satisfactory in both the original study, in which the Cronbach's Alpha Coefficients ranged from .66 to .89 (J elfs et al., 2009) and in the current study, in which they ranged from .69 to .88. Confirmatory Factor Analysis (CFA) was conducted to confirm the five-factor model. Considering the standardised path diagram and the obtained fit indices, it is concluded that the CFA results provided sufficient evidence for the factors $\left(\chi^{2}(485)=924.32, p<05\right.$, $\chi^{2} / \mathrm{df}=1.89, \mathrm{RMSEA}=.080, \mathrm{SRMR}=.084, \mathrm{RMR}=.056, \mathrm{PNFI}=.557, \mathrm{CFI}=.881$ ).

A semi-structured interview schedule with probing questions was developed in Turkish based on relevant literature and the research questions. For its content validity, two subject field experts examined the schedule and a pilot implementation was conducted with two participants. The final form had two sections and nine items, with four about tutors and five about advisors. The interview questions were about the characteristics of good tutors and advisors, their support for students' learning, motivation, and independent work, their advising process, and interaction with students.

\section{Data Analysis}

For the first research question, descriptive data analysis was conducted. For the second research question, Pearson correlation, Independent samples t-test, and MANOVA were conducted. For the third research question, qualitative data in the form of audio recordings were transcribed and the data were analysed using Constant Comparative Method (Glaser \& Strauss, 1965). As a guide, the five factors of the questionnaire were used as the main categories in the qualitative data analyses regarding students' perceptions and expectations from tutors. However, since the questionnaire has no items regarding advisors, the data about the advisors were analysed considering the advisor expectations listed by Wisker (2012). To establish trustworthiness (Lincoln \& Guba, 1985), triangulation was applied by comparing and combining interview and questionnaire data analyses in the findings section. Resulting categories and subcategories were reported with their occurrence frequencies. A member check was used and two researchers conducted qualitative analysis independently. The comparison of main and subcategories of the two researchers resulted in $78 \%$ agreement. Then, the two researchers refined the main and subcategories in order to reach total agreement.

\section{Results}




\section{Perceptions of Good Tutors Based on Questionnaire Data (Research Question 1)}

CT has the highest average mean score $(\mathrm{M}=4.44)$, followed by SE, and PC. PI and VG factors had relatively lower mean scores (Table 1). The participants' ratings for individual questionnaire items ranged between 3.48 and 4.59 , indicating positive perceptions for all listed tutor characteristics.

Table 1

Descriptive Analysis Results of the Factors in the Questionnaire

\begin{tabular}{lrc}
\hline Factors in the questionnaire & M & SD \\
\hline Critical Thinking (CT) & 4.44 & .41 \\
Subject Expertise (SE) & 4.40 & .52 \\
Pastoral Care (PC) & 4.23 & .53 \\
Promoting Interaction (PI) & 3.86 & .72 \\
Vocational Guidance (VG) & 3.67 & .99 \\
\hline
\end{tabular}

Note. 1: Strongly Disagree, 5: Strongly Agree.

\section{Variations in the Perceptions of Good Tutor Characteristics (Research Question 2)}

There was negative, significant, and low correlation between participants' age and their good tutor perceptions in terms of PI ( $r=-21)$, VG ( $r=-.17)$, and PC $(r=-.17$; Table 2). This indicates that the younger the student, the higher their perceptions of good DE tutors for these factors.

Significant differences were found in the participants' ratings when their gender, university, subject field, and previous online learning experience were examined. There was a significant mean difference between male and female students for SE and PC factors. Male students had higher mean scores $(\mathrm{p}<.01)$ in both factors. There were also significant differences in results among the two universities and their programmes. The students at U2 had higher mean scores than those at U1 on CT, VG, and PI factors. MANOVA results showed a significant multivariate main effect for subject field with Pillai's Trace $=.25, F(15,411)=2.46$, $\mathrm{p}<05$, with effect size of .08. Follow-up ANOVA tests were conducted and tested based on $\mathrm{p}<.01$ using the Bonferroni method due to several comparisons. Although there was no significant difference between the three programmes at U2, the students registered to HIM and NH programmes at U2 had higher mean score on PI factor than students registered to the CT programme at U1.

For the VG factor, there was a significant mean difference between participants who had previous online learning experience and those who did not. Students who had previous learning experience had higher ratings for this factor. The number of semesters spent in the programme did not have a statistically significant impact on student perceptions. 
Table 2

Summary of Results for Research Question 2

\begin{tabular}{|c|c|c|c|c|c|c|c|}
\hline Variables & Analysis & CT & VG & SE & PI & PC & $\begin{array}{l}\text { Conclusion } \\
\text { based on } \\
p<.01\end{array}$ \\
\hline Age & $\begin{array}{l}\text { Pearson } \\
\text { correlation }\end{array}$ & - & $\mathrm{p}<05$ & - & $\mathrm{p}<05$ & $\mathrm{p}<05$ & $\begin{array}{l}\text { Significant } \\
\text { Relationship } \\
\text { VG, PI, PC }\end{array}$ \\
\hline$r$ & & -.16 & -.17 & -.06 & -.21 & -.17 & \\
\hline $\begin{array}{l}\text { Gender } \\
\text { (M/ F) }\end{array}$ & $\begin{array}{l}\text { Independent } \\
\text { samples } \\
\text { t-test }\end{array}$ & - & - & $p<05$ & - & $p<01$ & $\begin{array}{l}\text { Significant } \\
\text { differences for } \\
\text { SE: } M>F \\
\text { PC: } M>F\end{array}$ \\
\hline Cohen's d & & .17 & .21 & .44 & .11 & .49 & \\
\hline $\begin{array}{l}\text { University } \\
\text { (U1/ U2) }\end{array}$ & $\begin{array}{l}\text { Independent } \\
\text { samples } \\
\text { t-test }\end{array}$ & $p<05$ & $p<05$ & - & $\mathrm{p}<01$ & - & $\begin{array}{l}\text { Significant } \\
\text { differences for } \\
\text { CT: U2>U1 } \\
\text { VG: U2>U1 } \\
\text { PI: U2>U1 }\end{array}$ \\
\hline Cohen's d & & .40 & .40 & .02 & .66 & .11 & \\
\hline $\begin{array}{l}\text { Subject Field } \\
(\mathrm{EAP}, \mathrm{HIM}, \\
\mathrm{NH}, \mathrm{CT})\end{array}$ & MANOVA & - & - & ap $<05$ & $\mathrm{p}<01$ & - & $\begin{array}{l}\text { Significant } \\
\text { differences for } \\
\text { PI: HIM }>C T \\
(p<01) \\
N H>C T(p<01) \\
\text { No significant } \\
\text { difference for } \\
\text { aSE: HIM }>N H \\
(p>01)\end{array}$ \\
\hline Partial $\eta^{2}$ & & .05 & .04 & .06 & .13 & .03 & \\
\hline $\begin{array}{l}\text { Previous } \\
\text { Online } \\
\text { Learning } \\
\text { Experience }\end{array}$ & $\begin{array}{l}\text { Independent } \\
\text { samples } \\
\text { t-test }\end{array}$ & - & $\mathrm{p}<01$ & - & - & - & $\begin{array}{l}\text { Significant } \\
\text { difference for } \\
\text { VG: Previous } \\
\text { Experience>No } \\
\text { Experience }\end{array}$ \\
\hline Cohen's d & & .10 & .64 & .07 & .31 & .26 & \\
\hline $\begin{array}{l}\text { Completed } \\
\text { Semesters } \\
(1,2) \\
\text { Cohen's d }\end{array}$ & $\begin{array}{l}\text { Independent } \\
\text { samples } \\
\text { t-test }\end{array}$ & 09 & 08 & 28 & 04 & 33 & $\begin{array}{l}\text { No significant } \\
\text { difference }\end{array}$ \\
\hline
\end{tabular}

Note. CT: Critical Thinking, VG: Vocational Guidance, SE: Subject Expertise, PI: Promoting Interaction, PC: Pastoral Care.

a Bonferroni correction has been applied to individual ANOVA ( $p<01)$. 


\section{Perceptions of and Expectations from Good Tutors and Advisors (Research Questions 1 and 3)}

A comparison of quantitative and qualitative data analysis results for triangulation showed complementary findings. In reporting the interview results, the 11 participants are represented with letters A to K.

For students' perceptions of good tutors, the major theme was Critical Thinking, which included three main categories: instructional approach, presentation, and evaluation. The students appreciated tutors' use of both online $(n=4, A B F G)$ and video lectures $(n=3, B C H)$. However, they complained about the overuse of the presentation method and expected tutors to use alternative methods, constructivist, and studentcentred approaches ( $n=7, A C D E F H K)$, and to adapt their lectures specifically for $D E$ ( $n=1, C)$. The students expected tutors not to read lecture notes or presentation slides ( $n=6, B C D G H K)$, but to give in-depth and easy to understand explanations ( $n=2, B I)$. They wanted lectures to be well planned $(n=2, A C)$, interesting $(n=8, B C D E F H I K)$, of satisfying depth $(n=3, C F K)$ with useful visuals and videos $(n=4, C G I J)$, and with various concrete, real-life examples that facilitate understanding the application of theories $(n=9$, ABCDFGIJ K). This result complements the quantitative analysis results that students perceived a good tutor should provide stimulating and interesting lessons that facilitate critical thinking.

Although the evaluation category was not included in the questionnaire, interview results showed that students wanted their tutors to use alternative evaluation methods rather than written tests to determine students' overall performance ( $\mathrm{n}=2, \mathrm{CK})$. They desired their tutors to assign individual, interesting, and useful homework $(n=2, H K)$, give adequate information about the exams $(n=2, B H)$, and to have fair and sound evaluation methods ( $n=3, \mathrm{CJ} K)$.

Regarding interaction and communication, the students perceived that their tutors should make use of a variety of tools and methods for communication and interaction $(n=5, A B C I J)$ provided in their LMS ( $n=3$, $\mathrm{CFH}$ ) or with social media ( $n=5, A B G I)$, and should give information about these tools $(n=2, D K)$. The questionnaire did not include a category about DE tools and technologies for communication. In the interviews the students argued that there should be a mutual effort in establishing student-tutor communication ( $n=3, B C D$ ). Similar to the questionnaire results, the students expected tutors to promote and facilitate student-student communication, discussion, and sharing $(n=4, A B I K)$. However, the students had different opinions about the use of group projects $(n=2, A K)$. Moreover, tutors were expected to moderate the discussions and questions in online lectures effectively $(n=2, A K)$, and encourage students to ask questions and answer vocally rather than textually in order to minimise misunderstandings of written communication $(\mathrm{n}=2, \mathrm{DI})$.

In the Pastoral Care theme, two categories emerged similar to the questionnaire results: giving feedback and attitude toward helping students. The students expected their tutors to answer their questions in a timely manner ( $\mathrm{n}=10, \mathrm{ABCDFGHIJ} \mathrm{K})$ and for all students $(\mathrm{n}=3, \mathrm{ACJ})$. They expected tutors to read their assignments $(n=2, B K)$, provide them with timely, regular, frequent, adequate, and mostly written feedback with suggestions $(n=9, A B C D E F G H J)$. Similar to the results of the questionnaire's data, good tutors motivate students $(n=1, D)$, understand the challenges of adult $D E$ learners $(n=2, D G)$, have interest in helping students ( $n=5, C D G H K)$, devote time for their students $(n=4, A D J K)$, know their students and their names $(n=1, C)$, and take students' opinions into account in course decisions $(n=1, F)$. Tutors should provide 
them with their available times for contact $(n=1, F)$ and be able talk to them on the phone ( $n=5$, BDGHI). They perceived that good tutors are devoted to their profession as educators $(n=3, D G J)$ and tutors $(n=1$, $\mathrm{J})$.

In addition to the questionnaire results for Subject Expertise, three categories were found in the interview results: subject field expertise, distance communication skills, and technology expertise. Students reported that good tutors know content area well ( $n=2, D G)$, answer questions satisfactorily $(n=1, H)$, and bring different approaches and trends to discussions $(n=1, K)$. However, students perceived that subject field expertise is not adequate and a good tutor should know how to communicate that material in the best way using technology ( $\mathrm{n}=2, \mathrm{BG}$ ). Tutors were expected to have adequate knowledge and skills in technology $(\mathrm{n}=6, \mathrm{EFGHIJ})$, including computers, Internet tools, and LMS as well as skills in online course management, troubleshooting ( $n=2, H I)$, and creating graphics and visuals for their courses $(n=1, G)$.

Vocational Guidance theme was rarely mentioned in the interviews and it is also the lowest-rated category in questionnaire results. Interview participants appreciated when tutors emphasise topics and skills that will be useful for their future career $(n=1, E)$. However, they do not want to use the time in online lectures for vocational guidance $(n=2, J K)$. The following quote represents some of the common challenges the interview participants encountered:

Tutors read text during videos and students become bored... we should be able to talk, discuss a variety of topics. Lecture, lecture, lecture, up to a point. After a while I want to talk, discuss lots of other things, about articles, recent information. Tutors cannot answer all the e-mails, so the students try to ask questions about the things they don't understand during [online] lectures. Everyone is the same, they don't watch the lecture videos, and then when they ask questions there, it becomes a mass of questions. (K)

Regarding the expectations from their advisors, 12 categories were refined based on Wisker's (2012) list, which outlines 12 expectations students have of their research advisors. In the interviews, the most frequently stated expectations concerned advisors' guidance. Students expected to receive early guidance with clear explanations ( $n=7$, ABCEFGK), and continual guidance with scaffolding as their research progresses ( $n=7$, BEGHIJK) and as students get more independent ( $n=6, A B E D G I)$. They want to be informed during critical points where their research might go astray ( $n=4$, CDJK). Students needed guidance about topic selection ( $n=7$, BEDFHIJ), gaps in the literature and problem statements ( $n=10$, BCDEFGHIJK), and the scale of the research $(n=6, B E D H I J)$. They wanted advisors to guide them to topics that were not only timely and important but also interesting, doable, and useful for students ( $\mathrm{n}=6, \mathrm{BEDFIJ})$. They wanted advisors to help them with searching literature and access resources ( $n=7$, ABEGIJK), and to provide them with exemplary articles ( $n=4$, AGIJ). They also needed guidance for the design of the study ( $n=3$, AJK), methods $(n=4, B C I J)$, data collection $(n=7$, ABCFGJK), and writing $(n=3$, EIK). During this continual guidance, they wanted advisors to thoroughly read, examine, and comment on their reports ( $n=7$, ADEFHIJ), and to give formative feedback instead of summative ( $n=6$, CDEHIJ). They strongly desired timely feedback for their work ( $n=7$, ABCFHIK), and the provision of constructive criticism with suggestions $(n=6$, BCDFIJ) and praise $(n=2, A D)$. For example, one student reported: 
First, I want to receive feedback when I ask a question... Second, he/ she has to be the subject field expert, I mean, we learn at least the theory, the steps of the project, but during application, when I ask one-on-one, or how it will be, he/ she has to help me. Third, he/ she has to motivate me regarding the project. This is very important to me because sometimes you may really feel drained as we are working, have our own troubles, and among other things, we try to get a graduate degree too. (I)

Expectations for advisors to be available, friendly, and supportive were reported frequently. Availability of an advisor with timely replies to questions was the most important issue for the students ( $n=6, A B H I J K)$ and they preferred telephone as the main communication media for questions ( $n=11, \mathrm{ABCDEFGHIJ} \mathrm{K).}$ They wanted their advisors to arrange office hours so that they can call them without hesitation ( $\mathrm{n}=4, \mathrm{ABCF})$ or to provide remedial online sessions $(n=2, B I)$. They appreciated advisors who are open, friendly, understanding, supportive, ready to help, and approachable ( $\mathrm{n}=9, \mathrm{CBDFGHIJ} \mathrm{K})$. They wanted advisors to share interest in their research $(n=2, D K)$, value their research and efforts $(n=2, A D)$, and to motivate $(n=6$, ABDEIK). They also wanted their advisors to initiate communication occasionally by calling students to check on their progress ( $n=3, B C D$ ) and encourage students to share and communicate with other students $(n=3, D I J)$.

The students also valued their advisors' knowledge and expertise in research and methodology ( $\mathrm{n}=2, \mathrm{GI})$, their original ideas, and their efforts to keep up with the field $(n=1, G)$. They appreciated advisors who support, motivate, and guide students for publishing and help students prepare research for publication in their career $(n=3, B E I)$.

\section{Discussion}

\section{Learning Environment}

Participants criticised tutors' dull presentations, minimal interaction with students, and failure in online discussion moderation. They desired motivating, interesting, stimulating, and resourceful learning environments where they are allowed to be independent learners and can discuss and engage in critical thinking. The theory of Transactional Distance also suggests that course structure needs to be organised for challenging students' cognitive abilities (Moore, 1993). The participants required support for improving their critical thinking skills (Abdulla, 2004; J elfs et al., 2009) and they desired meaningful and real-life applications of learning to improve their writing and research (Holzweiss et al., 2014). Moreover, they wanted to be acknowledged for their potential and for their work (Edwards et al., 2011).

The learning environment must be flexible so that tutors can implement various teaching strategies to meet students' learning needs (Howland \& Moore, 2002). With diverse backgrounds of DE graduate students (Wisker, 2012), discussions can be used more effectively to improve students' critical thinking and their perspectives about controversial issues in their fields. Therefore, training for new DE tutors should ensure that they are equipped with appropriate strategies for distance learning environments. 
Supporting interactions between students is especially important for their socialisation. However, in the current study, although students expected to be in contact with their classmates, their preference for collaborative work varied. Some preferred not to be involved in collaborative work because of communication and task completion problems with their teammates over distance (Capdeferro \& Romero, 2012). To allow for such individual preferences, collaborative work could be optional. However, tutors should still employ a variety of tools and methods of communication and collaboration for those who wish to collaborate and not feel isolated. As social groups lead students to perseverance and success, advisors should support students to participate in academic communities for sharing, learning, and emotional support including reading and writing groups, online forums, seminars, workshops, and social networks (Wisker, 2012).

Regarding assessment, written tests may not be appropriate to measure problem solving, as argued by the participants. Similar to Holzweiss et al. (2014), the participants desired to engage in authentic work to apply theory into practice. Considering the increasing capabilities of Internet technologies and resources, a variety of online assessment methods including authentic tasks, problem-solving activities, and performance assessment can be used with formative evaluation (Oosterhof, Conrad, \& Ely, 2008).

\section{Interaction}

Participants desired quality interaction with their tutors and advisors (Schroeder et al., 2016) and perceived them as primary sources of academic support (Cain et al., 2007). They perceived that providing feedback is the most important characteristic of a good DE tutor (Cain at al., 2007; Edwards et al., 2011; Howland \& Moore, 2002; Lessing \& Schulze, 2002) and expected quality and individualised feedback. They wanted advisors to give guidance and scaffolding and to give forewarnings in the research process before making vital decisions for their research. They also wanted advisors to reduce guidance as students become more independent, to monitor their progress throughout the stages of research, to provide adequate examples and resources, and to provide guidance for publication. Some participants requested remedial sessions (Lessing \& Schulze, 2002). However, interview results showed that some students hesitate to make contact with their tutors and advisors, preferring not to disturb them. Therefore, they want them to have strict virtual office hours and want to be able to contact them on the phone to discuss complex problems (Howland \& Moore, 2002). Moreover, they want communication to be initiated mutually and they want their advisors to be interested and excited about their students' research. Clear and polite communication is appreciated (Wisker, 2012). As stated by the participants of this study, a good tutor and advisor needs to be committed to the profession as it requires individual attention, support, and mentoring (Holzweiss et al., 2014; Young, 2006). Research advisors may need to be trained through workshops and consultation with experienced mentors for effective supervision of DE students' research (Lessing \& Schulze, 2003).

\section{Expertise}

Participants agreed that good tutors and advisors know their field (Abdulla, 2004; Edwards et al., 2011; J elfs et al., 2009), keep up with new research, and apply these to their courses and supervision. Tutors are expected to have skills and expertise in technology, troubleshooting, online course management, and creating visual course materials. However, Abdulla (2004) found that students just expect basic technical competencies from their tutors. Howland and Moore (2002) suggest that integrating new technologies just because they are popular may increase the technical problems tutors and students will experience in DE. 
Any lack of tutor competency in using technology may decrease their teaching efficiency. Therefore, it is essential for inexperienced DE tutors to have hands-on training to effectively integrate technology into their courses.

\section{Individual Differences}

Although most of the participants perceived that a good DE tutor promotes interaction and provides Pastoral Care, younger students had higher expectations of tutors. This finding might suggest that these two factors relate to students' self-regulation skills which may develop over time with experience. Moreover, students' preference and level of independent learning may influence their expectations from their tutors (Howland \& Moore, 2002).

Similarly, as within J elfs, Richardson, and Price's (2009) research, younger participants expected more Vocational Guidance. Participants in U2, and participants with previous online learning experience also expected more Vocational Guidance. However, this factor had the lowest mean scores from the questionnaire and was rarely mentioned in the interviews. The interview participants were all employed during data collection, which may explain their lack of attention to this factor. The study by Holzweiss et al. (2014) suggests that while online discussion forums are useful for vocational peer information exchange, students may not consider it as a priority expectation from tutors and advisors.

Promoting Interaction showed differences in terms of university and subject field. This suggests that graduate students' perceptions of good tutors in terms of Promoting Interaction may vary depending on the DE context including styles of interactive teaching strategies of tutors, subject field, LMSs, and university culture, probable since DE learning environments may affect students' perceptions and satisfaction (Trinidad, Aldridge, \& Fraser, 2005). The disciplinary differences may further affect the conception of a good tutor (J elfs et al., 2009).

\section{Conclusion, Implications, and Recommendations for Further Research}

Being a tutor and advisor in DE programmes usually necessitates an increase in workload (Pattillo, 2005). Tutors and advisors have to adapt to new teaching styles and new technology (Wisker, 2012). The main challenges of supervisors include students' unrealistic expectations regarding the effort and time needed to complete their research, students' poor writing abilities, and poor work standard (Lessing \&Schulze, 2003). However, DE graduate students have various expectations from their tutors and advisors. Some of these expectations are unrealistic for tutors and advisors who are struggling with other responsibilities, while also expected to be available to students anytime, because this is a key premise of DE (Howland \&Moore, 2002; Wisker, 2012). DE students struggling to balance their work, family, and education may procrastinate due to work and family problems (Edwards et al., 2011; Kahu, Stephens, Leach, \&Zepke, 2013; Wisker, 2012). Therefore, negotiated and well-communicated expectations of tutors, advisors, and students may increase student satisfaction and programme quality. 
Guiding DE students is a unique challenge considering diverse student profiles, communication methods, technological competencies, and the integration of technology for communicating and collaborating with students (Wisker, 2012). Furthermore, novice advisors may need training on mentoring graduate students regarding the rules, conventions, and trends of their disciplinary community. Recent attention on online doctoral education programmes reminds us that the education of doctoral students requires even more advanced support for students (Gardner \& Mendoza, 2010). As a lack of socialisation in the academic community may lead to student attrition (Lovitts, 2005), DE tutors and advisors should be strongly committed to DE. Training for time management skills may assist novice tutors and advisors.

Assessment activities should be reconsidered to challenge students' critical thinking with authentic projects. Requiring expertise, detailed planning, creativity, and time commitment from tutors and advisors, student-centred approaches that facilitate students' critical thinking skills should be emphasised. Self and peer evaluations can also be used (Howland \& Moore, 2002).

This study has implications to TD theory, supporting its main principles while reporting graduate students' perceptions as novice researchers who may need the support of dialogue, structure, and autonomy in their DE programmes. This current study provided desired tutor and advisor actions from the perspective of graduate students to optimise TD, highlighted theimportance of individual student characteristics in course design (Benson \& Samarawickrema, 2009; Huang, 2002; Huang et al., 2016; Stein et al., 2005), and established the importance of interaction and flexibility to meet students' learning needs.

Although conducted in the Turkish context, findings can be used in the design and improvements of DE courses in similar programmes. In this current study, although generalisability of thefindings was increased by collecting data from two representative universities in Turkey, results might still be limited because the interviews were conducted in only one programme. The study can be repeated with a more representative groups of students from all types of disciplines in a variety of graduate programmes and also with doctoral DE students.

Moreover, further studies can be conducted on the relationship between students' expectations and their satisfaction in a longitudinal study. Further qualitative research can be conducted to explore the expectations of students from different age groups since the age of the participants of the qualitative phase of this study was low. Finally, tutor and student personalities, content, and students' levels may determine the level of dialogue and interaction students prefer within a DE course (Moore, 1993). Therefore, for quality online graduate classes, there is potential for research on ideal frequency, duration, depth of discussions, as well as consideration of students' individual differences and capabilities of the tutors and advisors.

\section{Acknowledgements}

A part of this study was presented at the 9th International Computer and Instructional Technologies Symposium held on 20-22 May, 2015 in Afyonkarahisar, Turkey. 


\section{References}

Abdulla, A. G. (2004). Distance learning students' perceptions of the online instructor roles and competencies. Doctoral Dissertation. Tallahassee, Florida: Florida State University.

Allen, I. E., Seaman, J ., Poulin, R., \& Straut, T. T. (2016). Online report card: Tracking online education in the United States. Babson Park, MA: Babson Survey Research Group and Quahog Research Group.

Bawane, J ., \& Spector, J . M. (2009). Prioritization of online instructor roles: Implications for competency-based teacher education programs. Distance Education, 30(3), 383-397. http:/ / dx.doi.org/ 10.1080/01587910903236536

Benson, R., \& Samarawickrema, G. (2009). Addressing the context of e-learning: Using transactional distance theory to inform design. Distance Education, 30(1), 5-21. https:/ / doi.org/ 10.1080/01587910902845972

Cain, D. L., Marrara, C., Pitre, P. E., \&Armour, S. (2007). Support services that matter: An exploration of the experiences and needs of graduate students in a distance learning environment. International J ournal of E-Learning \& Distance Education, 18(1), 42-56. Retrieved from http:// www.ijede.ca/ index.php/jde/ article/ view/ 129

Capdeferro, N., \& Romero, M. (2012). Are online learners frustrated with collaborative learning experiences? The International Review of Research in Open and Distributed Learning, 13(2), 2644. http:// dx.doi.org/ 10.19173/irrodl.v13i2.1127

Creswell, J . W. (2007). Research design: Qualitative, quantitative, and mixed methods approaches. Thousand Oaks, CA: Sage.

Dennen, V. P., Darabi, A. A., \& Smith, L. J . (2007). Instructor-learner interaction in online courses: The relative perceived importance of particular instructor actions on performance and satisfaction. Distance Education, 28(1), 65-79. http:// dx.doi.org/ 10.1080/01587910701305319

Edwards, M., Perry, B., \&J anzen, K. (2011). The making of an exemplary online educator. Distance Education, 32(1), 101-118. http://dx.doi.org/ 10.1080/01587919.2011.565499

Gardner, S. K., \&Mendoza, P. (Eds.). (2010). On becoming a scholar: Socialization and development in doctoral education. Sterling, VA: Stylus.

Giossos, Y., Koutsouba, M., Lionarakis, A., \& Skavantzos, K. (2009). Reconsidering Moore’s transactional distance theory. European J ournal of Open Distance and E-Learning, 2009(2). Retrieved from http:/ / www.eurodl.org/ ?p=archives\&year=2009\&halfyear=2\&article $=374$

Glaser, B. G., \& Strauss, A. L. (1965). The constant comparative method of qualitative analysis. Social Problems, 12(4), 436-445. http:// dx.doi.org/ 10.1525/ sp.1965.12.4.03a00070 
Higher Education Council of Turkey. (2016). Öğrenci İstatistikleri [Student Statistics]. Retrieved J anuary 15, 2016 from https://istatistik.yok.gov.tr

Holzweiss, P. C., J oyner, S. A., Fuller, M. B., Henderson, S., \&Young, R. (2014). Online graduate students' perceptions of best learning experiences. Distance Education, 35(3), 311-323.

http:// dx.doi.org/ 10.1080/01587919.2015.955262

Howland, J . L., \& Moore, J . L. (2002). Student perceptions as distance learners in Internet-based courses. Distance Education, 23(2), 183-195. http:// dx.doi.org/ 10.1080/0158791022000009196

Huang, H. M. (2002). Student perceptions in an online mediated environment. International J ournal of Instructional Media, 29(4), 405-422. Retrieved from https:// www.learntechlib.org/p/64267/

Huang, X., Chandra, A., DePaolo, C. A., \& Simmons, L. L. (2016). Understanding transactional distance in web-based learning environments: An empirical study. British J ournal of Educational Technology, 47(4), 734-747. http:// dx.doi.org/ 10.1111/ bjet.12263

Jelfs, A., Richardson, J. T., \& Price, L. (2009). Student and tutor perceptions of effective tutoring in distance education. Distance Education, 30(3), 419-441.

http:// dx.doi.org/ 10.1080/01587910903236551

J oo, K. P., Andrés, C., \&Shearer, R. (2014). Promoting distance learners' cognitive engagement and learning outcomes: Design-based research in the Costa Rican National University of Distance Education. The International Review of Research in Open and Distributed Learning, 15(6). 188210. http:// dx.doi.org/ 10.19173/irrodl.v15i6.1908

Kahu, E. R., Stephens, C., Leach, L., \&Zepke, N. (2013). The engagement of mature distance students. Higher Education Research \& Development, 32(5), 791-804. http:/ / dx.doi.org/ 10.1080/07294360.2013.777036

Lemak, D. J ., Shin, S. J ., Reed, R., \& Montgomery, J . C. (2005). Technology, transactional distance, and instructor effectiveness: An empirical investigation. Academy of Management Learning \& Education, 4(2), 150-159. dx.doi.org/ 10.5465/ AMLE.2005.17268562

Lessing, A. C., \& Schulze, S. (2002). Postgraduate supervision and academic support: Students' perceptions. South African J ournal of Higher Education, 16(2), 139-149. http:/ / dx.doi.org/ 10.4314/ sajhe.v16i2.25253

Lessing, A. C., \& Schulze, S. (2003). Lecturers' experience of postgraduate supervision in a distance education context: Research in higher education. South African J ournal of Higher Education, 17(2), 159-168. http:// dx.doi.org/ 10.4314/ sajhe.v17i2.25309

Lincoln, Y. S., \& Guba, E. G. (1985). Naturalistic inquiry. Beverly Hills, CA: Sage. 
Lovitts, B. E. (2005). Being a good course taker is not enough: A theoretical perspective on the transition to independent research. Studies in Higher Education, 30(2), 137-154.

http:/ / dx.doi.org/ 10.1080/03075070500043093

Moore, M. G. (1989). Editorial: Three types of interaction. American J ournal of Distance Education, 3(2), 1-7. http:// dx.doi.org/ 10.1080/08923648909526659

Moore, M. G. (1993). Theory of transactional distance. Theoretical principles of distance education. American J ournal of Distance Education, 1(1), 22-38. http:// dx.doi.org/ 10.4324/9780203803738.ch5

Moore, M. G., \& Kearsley, G. (2011). Distance education: A systems view of online learning. Belmont, CA: Wadsworth Cengage Learning.

Oosterhof, A., Conrad, R. M., \& Ely, D. P. (2008). Assessing learners online. Saddleback River, NJ : Pearson.

Pattillo, G. (2005). Fast facts. College and Research Libraries News, 66(6), 500.

Risner, M., \& Kumar, S. (2016). Graduate student perceptions of a globally networked course. J ournal of Applied Research in Higher Education, 8(3), 287-301. http:/ / dx.doi.org/ 10.1108/J ARHE-01-2015$\underline{0009}$

Schroeder, S. M. (2012). Perceived advising needs of adult learners: A qualitative analysis of advising experiences among online, classroom, \& cohort adult learners. Doctoral Dissertation. Grand Forks, North Dakota: University of North Dakota.

Schroeder, S. M., Baker, M., Terras, K., Mahar, P., \& Chiasson, K. (2016). Desired and experienced levels of connectivity to an asynchronous, online, distance degree program. Online Learning, 20(3), 244263. http:// dx.doi.org/ 10.24059/olj.v20i3.691

Soong, B. M. H., Chan, H. C, Chua, B. C., \&Loh, K. F. (2001). Critical success factors for on-line course resources. Computers \& Education, 36(2), 101-120. https:// doi.org/ 10.1016/ S0360$\underline{1315(00) 00044-0}$

Stein, D. S., Wanstreet, C. E., Calvin, J ., Overtoom, C., \&Wheaton, J . E. (2005). Bridging the transactional distance gap in online learning environments. The American J ournal of Distance Education, 19(2), 105-118. https:// doi.org/ 10.1207/s15389286ajde1902_4

Stoessel, K., Ihme, T. A., Barbarino, M. L., Fisseler, B., \& Stürmer, S. (2015). Sociodemographic diversity and distance education: Who drops out from academic programs and why? Research in Higher Education, 56(3), 228-246. http:// dx.doi.org/ 10.1007/ s11162-014-9343-x 
Trinidad, S., Aldridge, J ., \& Fraser, B. (2005). Development, validation and use of the online learning environment survey. Australasian J ournal of Educational Technology, 21(1), 60-81. https:/ / doi.org/ 10.14742/ ajet.1343

Wisker, G. (2012). The good supervisor: Supervising postgraduate and undergraduate research for doctoral theses and dissertations. New York, NY: Palgrave Macmillan. http:// dx.doi.org/ 10.1007/ 978-1-137-02423-7

Young, S. (2006). Student views of effective online teaching in higher education. American J ournal of Distance Education, 20(2), 65-77. http:// dx.doi.org/ 10.1207/s15389286ajde2002 2

\section{Athabasca} University

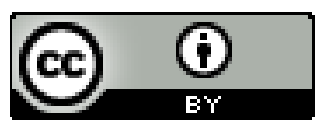

